\title{
THE FERTILIZING LIFE OF SPERMATOZOA IN THE FEMALE TRACT OF RABBITS AND FERRETS TREATED WITH OESTROGEN
}

\author{
M. G. GHANG AND ANNA L. SOUTHAM \\ Worcester Foundation for Experimental Biology, Shrewsbury, Massachusetts, U.S.A.
}

(Received 20th April 1970)

\begin{abstract}
Summary. Female rabbits and ferrets were inseminated long before ovulation occurred, by which time the fertilizing life of spermatozoa was nearly at an end. The proportion of fertilized eggs appeared to be higher in the females treated with oestrogen when the number of spermatozoa inseminated was reduced, but the difference was not statistically significant.
\end{abstract}

The fertilizing life of spermatozoa in the female tract was experimentally determined to be about $30 \mathrm{hr}$ in the rabbit (Hammond \& Asdell, 1926) and no more than $126 \mathrm{hr}$ in the ferret (Chang, 1965). This experiment was designed to examine whether the fertilizing life of spermatozoa in the female tract could be influenced by treatment of the female with oestrogen.

Mature female rabbits of mixed breeds, which had been isolated for at least 3 weeks, were used. They were artificially inseminated with a given number of spermatozoa collected by means of an artificial vagina from two or three fertile males. Some of the females were fed twice with $0.1 \mathrm{mg}$ ethinyl oestradiol in $1 \mathrm{ml}$ cottonseed oil, i.e. at $1 \mathrm{hr}$, and at $24 \mathrm{hr}$ after insemination. At $20 \mathrm{hr}$ after insemination, 80 i.u. of HCG was injected intravenously to induce ovulation, which occurred about $10 \mathrm{hr}$ later. Thus, insemination took place about $30 \mathrm{hr}$ before ovulation. As a rule, six females were inseminated with the same sperm suspension at any one time; three animals were fed with oestrogen and three animals served as controls. The animals were killed $24 \mathrm{hr}$ after the injection of HCG and following recovery from the Fallopian tubes, their eggs were mounted in toto, and examined before and after staining (Chang, 1952) to determine the proportion from each animal which had been fertilized. Ferrets in oestrus (as shown by the swollen vulva) at the end of the breeding season (August) were used. Their uterine horns were inseminated with epididymal spermatozoa suspended in Difco Lab. culture medium 199 (Ghang, 1965). Some of them were fed with $0.1 \mathrm{mg}$ ethinyl oestradiol daily for 5 days, starting 1 day after insemination. Ovulation was induced by an intraperitoneal injection of 80 i.u. of HCG 84 or $96 \mathrm{hr}$ after insemination. Since ovulation occurs about $30 \mathrm{hr}$ after injection of HCG in the ferret (McPhail, 1933; Ghang, 1965), insemination took place about 114 or $126 \mathrm{hr}$ before ovulation. As a rule, two experimental and two 
control animals at a time were inseminated with the same sperm suspension. The animals were killed 60 to $72 \mathrm{hr}$ after the injection of HCG. Their eggs were recovered, mounted, fixed and stained (Chang, 1965) in order to determine the proportion of fertilized eggs from each animal.

In the present experiment, the animals were inseminated long before the time of ovulation. At the time of ovulation, the fertilizing life of the spermatozoa is nearly ended in both the rabbit and the ferret. It was expected that, by comparing the proportion of fertilized eggs in the oestrogen-treated and control females, a beneficial or adverse influence of exogenous oestrogen might be

TABLE 1

FERTILIZING LIFE OF SPERMATOZOA IN THE FEMALE TRACT OF RABBITS AND FERRETS TREATED WITH OESTROGEN

\begin{tabular}{|c|c|c|c|c|}
\hline & $\begin{array}{c}\text { No. of } \\
\text { animals } \\
\text { used }\end{array}$ & $\begin{array}{c}\text { Average no. (and range) of } \\
\text { sperm. inseminated } \\
\times 10^{6} / \text { animal }\end{array}$ & $\begin{array}{l}\text { Total no. } \\
\text { of eggs } \\
\text { examined }\end{array}$ & $\begin{array}{c}\text { Total no. (and } \%) \text { of } \\
\text { fertilized eggs* }\end{array}$ \\
\hline $\begin{array}{l}\text { Rabbits inseminated } 30 \mathrm{hr} \\
\text { before ovulation } \\
\text { Oestrogen-treated } \\
\text { Control } \\
\text { Oestrogen-treated } \\
\text { Control }\end{array}$ & $\begin{array}{l}9 \\
9 \\
9 \\
9\end{array}$ & $\begin{array}{c}267(148 \text { to } 345) \\
63(46 \text { to } 73) \\
y\end{array}$ & $\begin{array}{l}68 \\
91 \\
82 \\
82\end{array}$ & $\begin{array}{l}41(60 \%) \\
57(63 \%) \\
21(26 \%) \\
11(13 \%)\end{array}$ \\
\hline $\begin{array}{l}\text { Ferrets inseminated } 114 \mathrm{hr} \\
\text { before ovulation } \\
\text { Oestrogen-treated } \\
\text { Control }\end{array}$ & $\begin{array}{l}8 \\
8\end{array}$ & $\begin{array}{c}10 \cdot 7(7 \cdot 3 \text { to } 13 \cdot 7) \\
"\end{array}$ & $\begin{array}{l}43 \\
70\end{array}$ & $\begin{array}{r}11(26 \%) \\
9(13 \%)\end{array}$ \\
\hline $\begin{array}{l}\text { Ferrets inseminated } 126 \mathrm{hr} \\
\text { before ovulation } \\
\text { Oestrogen-treated } \\
\text { Control }\end{array}$ & $\begin{array}{l}2 \\
2\end{array}$ & $\begin{array}{l}8 \cdot 3 \\
"\end{array}$ & $\begin{array}{l}23 \\
17\end{array}$ & $\begin{array}{l}5(22 \%) \\
0(0 \%)\end{array}$ \\
\hline
\end{tabular}

* No significant difference at the $5 \%$ level between experimental and control animals.

revealed. It can be seen from the results presented in Table 1 that there was no difference in the proportion of fertilized eggs between the oestrogen-treated $(60 \%$ of sixty-eight eggs) and control rabbits $(63 \%$ of ninety-one eggs) when a large number of spermatozoa was inseminated (148 to $345 \times 10^{6} / \mathrm{rabbit}$ ). When a relatively small number of spermatozoa (46 to $73 \times 10^{6} / \mathrm{rabbit}$ ) was inseminated, the proportion of fertilized eggs in the oestrogen-treated $(26 \%$ of eighty-two eggs) appeared to be higher than that in the control rabbit $(13 \%$ of eighty-two eggs). In the ferret, the proportion of fertilized eggs also appeared to be higher in the oestrogen-treated (22 to $26 \%$ ) than in the control ferrets (0 to $13 \%$ ). The fact that the ferrets were inseminated at the end of the breeding season, and the number of spermatozoa inseminated was rather low, 7.3 to $13.7 \times 10^{6}$, in comparison with a previous study, 16.6 to $23.5 \times 10^{6}$ (Chang, 1965), again points to the possibility that, as in the case of the rabbit, the beneficial effect of oestrogen treatment on the fertilizing life of spermatozoa can be revealed only when a small number of spermatozoa is deposited into the female tract. These differences, however, are not statistically significant at the 
$5 \%$ level. Even if a significant difference can be found by further reduction of the number of spermatozoa inseminated, the practical value of such treatment is still uncertain.

\section{REFERENCES}

Chang, M. C. (1952) Fertilizability of rabbit ova and the effects of temperature in vitro on their subsequent fertilization and activation in vivo. F. exp. Zool. 121, 351.

Chang, M. C. (1965) Fertilizing life of ferret sperm in the female tract. F. exp. Zool. 158, 87.

Hammond, J. \& Asdell, S. A. (1926) The vitality of spermatozoa in the male and female reproductive tracts. Br. F. exp. Biol. 4, 155.

MaPhaIl, M. K. (1933) Induction of ovulation in the unmated oestrous ferret. F. Physiol., Lond. 80, 78. 